\title{
The use of nematodes in assessing ecological conditions in shallow waters surrounding a Mediterranean harbour facility
}

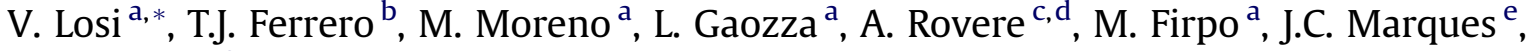 \\ G. Albertelli ${ }^{\mathrm{a}}$ \\ a Dipartimento di Scienze della Terra, dell'Ambiente e della Vita (DISTAV), University of Genoa, Corso Europa 26, 16132 Genoa, Italy \\ ${ }^{\mathrm{b}}$ Natural History Museum, Life Sciences Department, Cromwell Road, London SW7 5BD, UK \\ ' SEAMap srl - Environmental Consulting, Via Greto di Cornigliano 6r, 16152 Genoa, Italy \\ ${ }^{\mathrm{d}}$ Lamont-Doherty Earth Observatory, Columbia University, P.O. Box 1000, 61 Route 9W, Palisades, NY 10964, USA \\ e IMAR - Institute of Marine Research, Department of Life Sciences, Faculty of Sciences and Technology, University of Coimbra, 3004-517 Coimbra, Portugal
}

\section{A R T I C L E I N F O}

\section{Article history:}

Received 30 October 2012

Accepted 28 February 2013

Available online 14 March 2013

\section{Keywords:}

free-living nematodes

human impact

harbours

environmental quality assessment

bioindicators

Mediterranean Sea

\begin{abstract}
A B S T R A C T
The spatial distribution and structure of nematode assemblages in the area surrounding the harbour of Vado Ligure (Savona, NW Mediterranean) were studied in relation to the influence of natural and anthropogenic environmental factors. Stations were selected following an "anthropogenic gradient" from sites located near the city centre and its harbour to more pristine and distant sites. Sediment quality was determined by considering both sediment granulometric and chemical parameters (hydrocarbons, heavy metals, total organic matter, proteins, carbohydrates) as well as nematode abundance, diversity, life strategies, trophic structure and assemblage composition. A high correlation between environmental characteristics and the nematode response was found. On the basis of the comparison of these results, which identified three distinct sub-areas associated with different levels of environmental quality, a set of nematode indicator genera was selected for the future evaluation of quality status.
\end{abstract}

(c) 2013 Elsevier Ltd. All rights reserved.

\section{Introduction}

Shallow coastal habitats are subject to intense environmental pressure with extensive feedback effects between natural and human systems (Turner, 2000). As well as natural fluctuations in abiotic parameters, the input of nutrients, organic matter and pollutants related to anthropogenic activities can further modify coastal environmental conditions, sometimes to a greater extent, and produce changes in the biota different to those derived from natural variability alone (Turner et al., 1995; Venturini et al., 2004). The multiple uses of coastal areas can mobilize terragenic materials to the marine environment in amounts similar to, or even exceeding, those introduced through natural weathering processes (Bruland et al., 1974). In the Mediterranean Sea, the effects of urbanization, port and harbour development, industrial activities, agriculture and aquaculture, have resulted in extensive coastal pollution (Haas, 1989). Liguria, an administrative region of NW Italy (NW Mediterranean Sea), has been subject to significant urban and industrial coastal development since the 1960s, which, together with high tourism, has concentrated both civil and industrial

\footnotetext{
* Corresponding author.

E-mail addresses: valentina.losi@unige.it, losivalentina@gmail.com (V. Losi).
}

activities in a narrow, highly populated territory (Bertolotto et al., 2005; Montefalcone et al., 2009). In particular, the area of Vado Ligure (Savona, Ligurian Sea, NW Mediterranean) has a long history of industrial and harbour activities, with long tracts of the coastline dedicated to tourism. Anthropogenically stressed coastal areas such as these typically receive inputs which may contain hydrocarbons, heavy metals and other pollutants derived from human activities, that cause perturbations in the ecosystem, changing the abiotic conditions and influencing the biota in terms of density, diversity, structure and functioning (Venturini et al., 2004; Martínez-Lladó et al., 2007).

The use of indicators to detect and monitor environmental conditions is of primary importance and represents a worldwide incentive, detailed in the Water Framework Directive (WFD, 2000/ 60/EC) and Marine Strategy Framework Directive (MSFD, 2008/56/ $\mathrm{EC})$. Living organisms are fundamental in assessing the ecological status of an ecosystem, integrating both biotic and abiotic components through their adaptive responses (Casazza et al., 2002). Whilst contaminant concentrations in the water column can change significantly, both temporally and spatially, sediments integrate contaminants over time, accumulating natural and anthropogenic products from the overlying water. As a consequence, benthic species, living in close contact with sediment particles and interstitial water, are intimately exposed to contaminants and therefore 
have been used historically as indicators of environmental quality. Benthic macrofauna is more usually employed as bioindicators than the meiofauna, despite the fact that in soft sediments, where contaminants accumulate, meiobenthic invertebrates frequently represent the most abundant metazoan organisms (Gerlach, 1971; Höss et al., 2011). Moreover, in severely polluted sediments, some meiofaunal taxa represent the only significant metazoan component, whereas macrofauna may be scarce and difficult to sample representatively, or dominated by high abundance of very few taxa, in both cases providing little information that can be used effectively (Kennedy and Jacoby, 1999). The use of meiofauna in biomonitoring studies gives many advantages over macroinvertebrates owing to their high abundance and diversity, small size, short life cycles, rapid development, limited mobility, absence of pelagic life stages and the presence of both tolerant and sensitive species. These advantages lead to more robust data sets, which can show higher sensitivity, effects over smaller spatial scales, and a quicker response to disturbance (Kennedy and Jacoby, 1999; Frontalini et al., 2011).

Of the meiofaunal taxa, nematodes in particular offer a variety of possibilities for assessing changes in assemblage structure, due to their high structural and functional diversity, as the most diverse and numerically dominant metazoans in aquatic habitats, with a wide distribution varying from pristine to extremely polluted habitats. Although nematodes have already been employed in environmental quality assessment studies and have proved to be suitable indicators for pollution-induced disturbances of benthic ecosystems (Coull and Chandler, 1992; Bongers and Ferris, 1999; Höss et al., 2011), they are not currently considered as a requirement for the assessment of the ecological status of the benthic environment according to the WFD and MSFD. However, the WFD has recently proposed nematodes as indicators for evaluation of the ecological quality status of marine ecosystems (Moreno et al., 2011). The use of nematode indices, especially in soft sediments, can bridge the gap in current monitoring programs, mainly based on macro-benthic invertebrates (Höss et al., 2011) revealing different and complementary aspects of the factors structuring benthic ecosystem, fundamental in ecological status assessment (Vanaverbeke et al., 2011).

In this study we evaluated the use of nematodes as indicators of environmental quality in an area strongly influenced by human activities. The main aims were to analyze patterns of nematode assemblages in the study area and to test whether: (1) there was a relationship between the observed patterns and the main environmental variables and human influences; (2) anthropogenic impacts had influenced the nematode assemblage structure; and (3) there were nematode genera which could be reliably used as indicators of pollution or environmental quality.

In order to achieve these objectives, inorganic (heavy metal) and organic (C12-C40, polycyclic aromatic hydrocarbons) pollutants as well as organic enrichment were investigated at twenty-two stations situated along an "anthropogenic gradient" from sites located near the city of Vado Ligure and its harbour to more pristine, distant sites. To account for the effects of natural environmental variability on the structure of nematode assemblages, relationships with depth, particle size and organic matter composition were also investigated.

\section{Materials and methods}

\subsection{Study area and field activities}

The study was carried out along the coast of Vado Ligure (Savona) in the Western Ligurian Riviera (Ligurian Sea, NW Mediterranean). The area is densely populated and influenced by the presence of a commercial port, which is an important container and oil terminal, an oil-burning power plant and by various other economic activities, such as industrial plants and tourist resources. Samples were collected in January 2010 at twenty-two stations located at increasing distance to the south of the centre of Vado Ligure and its harbour (Fig. 1). Sampling locations were determined with a Global Position System (GPS) receiver. At each station, three replicate sediment samples were collected by a modified Van Veen grab and subsampled for analyses of sediment grain size, sedimentary organic matter concentration and biochemical composition, contaminant concentrations (polycyclic aromatic hydrocarbons (PAHs), C12-C40 (C > 12) and heavy metals) as well as abundance and composition of nematode assemblages. At all sampling stations, for each deployment, transparent Plexiglas tubes (inner median diameter, $3.6 \mathrm{~cm}$ ) were used to collect sediment cores from the surface of the grab sample to a depth of $2 \mathrm{~cm}$. Sediment cores taken for nematode analysis were fixed with $4 \%$ buffered formaldehyde in $0.4 \mu \mathrm{m}$ pre-filtered seawater solution, while samples for later determination of environmental variables were frozen at $-20^{\circ} \mathrm{C}$.

\subsection{Grain size}

Grain size analysis was performed using a vibro-siever for fractions larger than $63 \mu \mathrm{m}$, and a sedigraph (SEDIGRAPH III 5120 Micrometrics) for those smaller than $63 \mu \mathrm{m}$. For the dry-sieving analysis, sediment was oven dried at $105^{\circ}$ for $24 \mathrm{~h}$, weighed, washed on a $38 \mu \mathrm{m}$ sieve in order to eliminate soluble salts and oven dried again for $24 \mathrm{~h}$. After the second drying, sediment was weighed, passed through a set of standard sieves (ASTM $1 / 2$ phi, diameter $=20 \mathrm{~cm}$ ) and shaken by an automatic shaker for seven minutes. The results were combined with the sedigraph results to give the full particle size distribution. Sediments were classified following the Udden and Wentworth scale (Wentworth, 1922).

\subsection{Sedimentary organic matter concentration and biochemical composition}

Total organic matter (TOM) was determined by loss on ignition according to Parker (1983). Protein concentration (Prt) was assessed according to the Hartree (1972) method, modified by Fabiano et al. (1995). Bovine albumin solutions were used as standards and absorbance was determined at $650 \mathrm{~nm}$. Carbohydrate concentration (Cho) was analyzed according to Dubois et al. (1956), modified for sediment application by Gerchakov and Hatcher (1972). D(+) glucose solutions were used as standards and absorbance was measured at $490 \mathrm{~nm}$. For each parameter, sediment blanks were analyzed following the same method, with sediment pre-treated at $550{ }^{\circ} \mathrm{C}$ for $4 \mathrm{~h}$. Concentrations were expressed as $\mathrm{mg} \mathrm{g}^{-1}$ of sediment dry weight (DW).

\subsection{Contaminants}

Concentrations of contaminants were carried out by the CIMA Research Foundation. The method used for the heavy metals was Aqua Regia ICP/MS. Concentrations of PAHs and C $>12$ were measured by the PAH-GCMS/MS and GC/FID method. Heavy metal and PAHs concentrations were compared with the ER-L (Effect Ranged-Low) and ER-M (Effect Ranged-Median) values reported for the sediment guidelines of the U.S. Environmental Protection Agency (USEPA) (Long et al., 1995). For each station, mean ER-M quotients were calculated for PAHs (ER-Lq PAHs) and heavy metals (ER-Lq Met) by dividing the concentrations of the individual compounds by their respective ER-M guidelines, summing these quotients and dividing by the number of analyzed compounds 


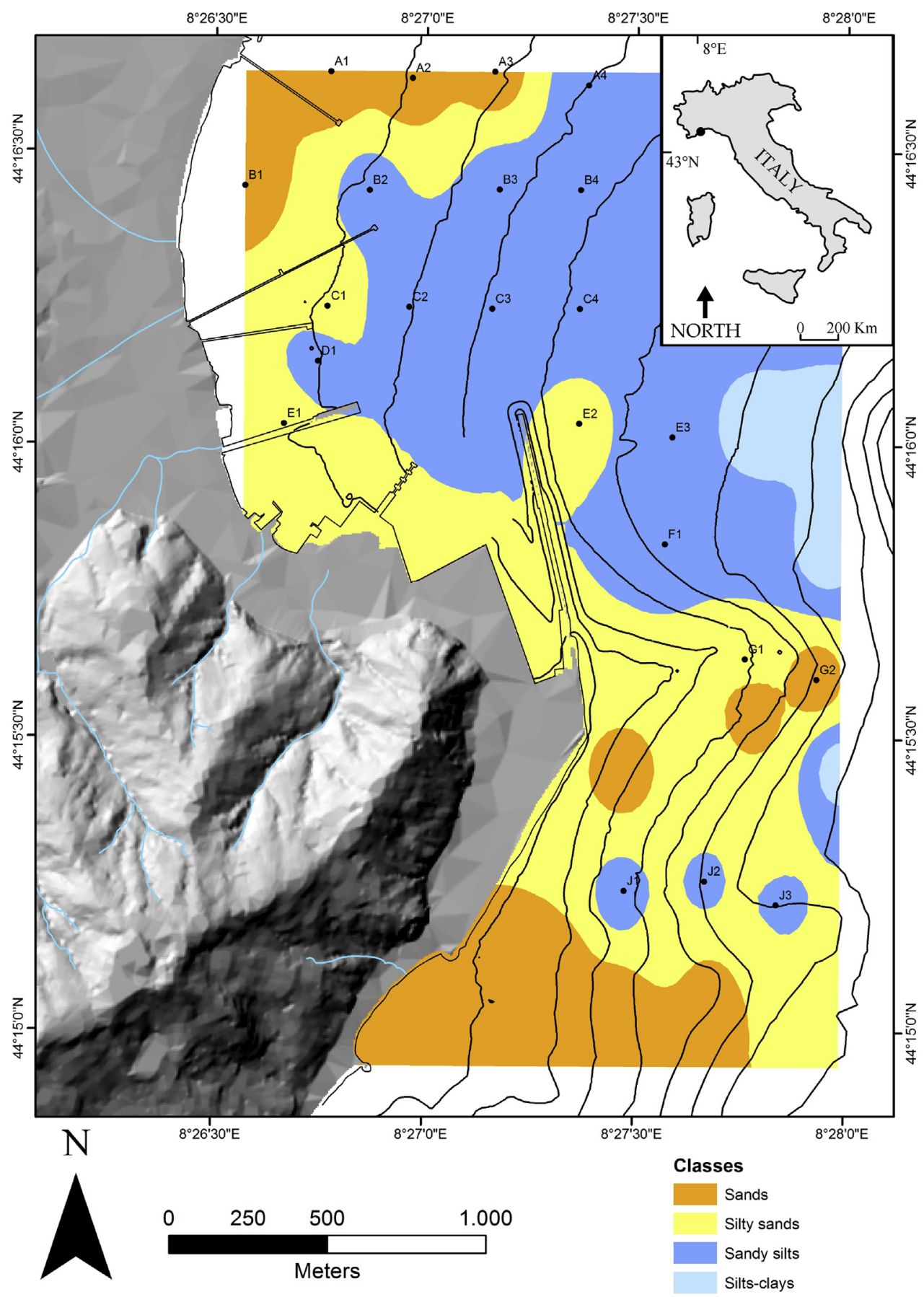

Fig. 1. Map of the study area and sampling stations with "x" metre depth contours and showing principal sedimentary habitats.

(Long et al., 1998). The method accounts for the presence of mixtures of toxic chemicals and the degree to which individual chemicals exceed their ER-M guidelines, assumes an additive effect toxicity (but not synergistic or antagonistic effects), and provides a useful means of ranking sites that have multiple contaminants (Long and MacDonald, 1998). ER-M values $\geq 1$ implies that biological adverse effects are likely to occur (Long et al., 1998). Mean ER-L quotients were also calculated in the same way as mean ER-M quotients. A mean ER-L quotient $\geq 1$ implies that at least one analyte exceeds the ER-L and therefore adverse biological effects are predicted to occur at relatively low frequency (Long and MacDonald, 1998; McCready et al., 2000).

\subsection{Nematode community}

In the laboratory, all meiofaunal samples were rinsed with a gentle jet of fresh water over a $0.5 \mathrm{~mm}$ sieve to exclude macrofauna, decanted over a $38 \mu \mathrm{m}$ sieve ten times, centrifuged three times with Ludox HS40 (specific density $1.18 \mathrm{~g} \mathrm{~cm}^{-3}$, according Heip et al. (1985)), and stained with Rose Bengal $\left(0.5 \mathrm{~g} \mathrm{~L}^{-1}\right)$. Meiofaunal organisms were counted and identified at the major taxon level, using a stereomicroscope. One-hundred nematodes from each replicate were randomly picked out using fine pin under a stereomicroscope (magnification $\times 40$ ), transferred from formalin to glycerol through a series of ethanol-glycerol solutions, and mounted on slides in 
anhydrous glycerine, following the procedure described by Heip et al. (1985). Nematodes were identified at genus level using the pictorial keys of Platt and Warwick $(1983,1988)$ and Warwick et al. (1998), as well as the NeMys online identification key (Steyaert et al., 2005) and additional taxonomic papers (e.g., Verschelde et al., 2006).

At each site total nematode abundance $(A)$ and number of genera $(S)$ were calculated; diversity and evenness were expressed as the Shannon-Wiener Index $\left(H^{\prime}, \log _{2}\right)$ and Pielou's evenness $\left(J^{\prime}\right)$ respectively.

Nematode genera were classified according to Wieser (1953) into four feeding groups to investigate the trophic structure of the assemblages: selective (1A) and non-selective (1B) deposit feeders, epistrate feeders (2A), and predators/omnivores (2B). The Index of Trophic Diversity (ITD) was calculated according to Heip et al. (1985), ranging from 0.25 (the highest trophic diversity) to 1.0 (the lowest trophic diversity).

The maturity index (MI, Bongers, 1990; Bongers et al., 1991) was calculated as the weighted average of the individual coloniserpersister $(\mathrm{c}-\mathrm{p})$ values:

$\mathrm{MI}=\sum v(i) f(i)$

where $v$ is the $\mathrm{c}-\mathrm{p}$ value of genus $i$ and $f(i)$ is the frequency of that genus. This index has been proposed as a semiquantitative value giving an indication of ecosystem conditions according to the nematode assemblage composition.

\subsection{Statistical analyses}

Spearman's Rank Correlation Analysis was conducted to elucidate the relationships between biotic and abiotic variables. A correlation matrix (Spearman's rho) was calculated for environmental variables, assemblage parameters and relative abundance of relevant genera.

To ascertain if the studied environmental variables explained changes in nematode assemblages, non-parametric multivariate multiple regression analyses, based on Euclidean distances, was carried out using the routine DISTLM forward (McArdle and Anderson, 2001). The forward selection of the predictor variables was carried out with tests by permutation. All tests were based on Bray-Curtis dissimilarities, calculated between observations for log-transformed nematode data. P values were obtained using 4999 permutations of raw data for the marginal tests (tests of individual variables), while for all of the conditional tests, the routine uses 4999 permutations of residuals under a reduced model. Principal component analysis (PCA) using normalized Euclidean distance was carried out on environmental variables that proved to be most important in structuring the nematode assemblages according the DISTLM forward analysis.

A constrained ordination, a canonical correspondence analysis (CCA), was carried out to explicitly investigate the relationship between environmental variables and the community assemblage. In CCA plots, each vector for an environmental variable defines an axis, and site or genus scores can be projected onto that axis. An indication of relative importance of a vector is its length; the angle indicates correlation with other vectors and CCA axes. Eigenvalues for CCA axes indicate the importance of the axes in explaining relationships in the genera-environment data matrices (Fiscus and Neher, 2002 and refs therein). A Monte Carlo permutation was used to test statistically whether the genera were significantly related to the chosen environmental variables and to determine the significance of first and second axes.

Sensitivity or tolerance of nematodes was estimated by the relative influence of the contaminants impacts on genera using quadrants of the CCA bi-plot, assuming that abundant populations occur when a genus is tolerant or insensitive to a specific stress and that populations decrease when sensitive. Genera with a CCA score in the same quadrant as the hydrocarbons or metals were considered as insensitive to this kind of pollution, whilst genera that scored in the quadrant not influenced by contaminant vectors were regarded as sensitive to contamination; genera that fell in a quadrant influenced only by metal or hydrocarbons were assumed to have intermediate sensitivity/tolerance to that category alone. Finally, in order to classify a genus sensitive or tolerant it must occur in at least two samples.

A similar approach was used by Höss et al. (2011) who ranked fresh water nematode species according to their sensitivity to metal and organic contamination and by Fiscus and Neher (2002) who ranked soil nematode genera according to their sensitivity to physical and chemical disturbance.

All statistical tests were performed using R statistical software (R. Development Core Team, 2011).

\section{Results}

\subsection{Grain size}

The stations studied showed a large gradient of substrate type, with sediments varying from medium silt to very coarse sand and from very poorly to moderately sorted (Table 1 and Fig. 1 ).

Mean grain size values ranged between $0.03 \mathrm{~mm}$ (Station B2) and $5.82 \mathrm{~mm}$ (Station E1). A general pattern of decreasing grain size with depth was recorded $(p<0.05)$ due to the increase of clay $(p<0.001)$ and silt $(p<0.05)$ fractions with depth (Appendix A).

\subsection{Sedimentary organic matter concentration and biochemical composition}

The results for organic matter concentration and biochemical composition are reported in Table 1 . TOM showed a wide range of percentages from $1.28 \pm 0.03 \%$ (Station A1) to $24.77 \pm 0.17 \%$ (Station B4), with a pattern of increasing concentration with increasing depth $\left(p<0.05\right.$, Appendix A). Prt ranged between $0.05 \pm 0.01 \mathrm{mg} \mathrm{g}^{-1}$ of sediment DW (Station E1) and $1.51 \pm 0.15 \mathrm{mg} \mathrm{g}^{-1}$ of sediment DW (Station B4) and Cho between $0.24 \pm 0.02 \mathrm{mg} \mathrm{g}^{-1}$ of sediment DW (Station A2) and $8.65 \pm 0.04 \mathrm{mg} \mathrm{g}^{-1}$ of sediment DW (Station F1). Both Prt and Cho increased with depth ( $p<0.01$, Appendix A).

\subsection{Contaminants}

Concentrations of heavy metals, PAHs and C $>12$ varied greatly throughout the study area. Summary statistics of the different contaminants are shown in Table 2 and their standardized values are shown in Fig. 2.

Metals accounted for the majority of contaminants exceeding ER-L and ER-M limits. Concentrations of As appeared rather uniformly distributed, exceeding the ER-L limit at all stations with a maximum concentration recorded at Station C2 (34 ppm). Cd showed similar values, lower than ER-L limit, at all stations, with the exception of Station J1 (3.9 ppm), where it was almost twoorder of magnitude higher. $\mathrm{Hg}$ and $\mathrm{Pb}$ varied greatly throughout the surveyed area, $\mathrm{Hg}$ exceeding ER-L or ER-M limits at almost all the stations and $\mathrm{Pb}$ exceeding the ER-L limit at most of the stations. For both metals the highest values were recorded at Station C2 (3.4 and $128 \mathrm{ppm}$, for $\mathrm{Hg}$ and $\mathrm{Pb}$ respectively).

Concentration level of PAHs was generally quite low (on average $2.4 \mathrm{ppm}$ ); however, a few stations exceeded the value for ER-L but not for ER-M. Highest values of PAHs and C $>12$ were recorded at Station C2 (8010 $\mu \mathrm{g} \mathrm{kg} \mathrm{kg}^{-1}$ and $31,200 \mu \mathrm{g} \mathrm{kg} \mathrm{kg}^{-1}$ respectively). 
Table 1

Depth, sedimentological characteristics and organic matter concentration and biochemical composition at each sampling station.

\begin{tabular}{|c|c|c|c|c|c|c|c|c|c|c|}
\hline & $\begin{array}{l}\text { Depth } \\
(\mathrm{m})\end{array}$ & $\begin{array}{l}\text { Gravel } \\
(\%)\end{array}$ & $\begin{array}{l}\text { Sand } \\
(\%)\end{array}$ & $\begin{array}{l}\text { Silt } \\
(\%)\end{array}$ & $\begin{array}{l}\text { Clay } \\
(\%)\end{array}$ & $\begin{array}{l}\text { Grain size } \\
(\mathrm{mm})\end{array}$ & Sorting $\sigma$ & $\begin{array}{l}\text { TOM } \\
(\%)\end{array}$ & $\begin{array}{l}\text { Prt } \\
\left(\mathrm{mg} \mathrm{g} \mathrm{DW}^{-1}\right)\end{array}$ & $\begin{array}{l}\text { Cho } \\
\left(\mathrm{mg} \mathrm{g} \mathrm{DW}^{-1}\right)\end{array}$ \\
\hline $\mathrm{A} 1$ & 6.0 & 0.02 & 89.14 & 10.34 & 0.50 & 0.09 & 0.55 & 1.28 & 0.10 & 0.46 \\
\hline $\mathrm{A} 2$ & 10.5 & 0.29 & 89.02 & 9.80 & 0.90 & 0.09 & 0.55 & 1.53 & 0.09 & 0.24 \\
\hline A3 & 18.0 & 0.17 & 75.38 & 22.55 & 1.90 & 0.08 & 1.10 & 3.46 & 0.43 & 1.27 \\
\hline A4 & 30.0 & 5.38 & 21.33 & 65.39 & 7.89 & 0.04 & 2.93 & 8.78 & 1.32 & 7.40 \\
\hline B1 & 4.00 & 0.03 & 79.22 & 20.01 & 0.74 & 0.07 & 0.63 & 1.63 & 0.09 & 0.41 \\
\hline B2 & 11.5 & 0.09 & 24.80 & 62.28 & 12.83 & 0.03 & 2.25 & 2.16 & 0.27 & 0.70 \\
\hline B3 & 26.5 & 0.18 & 41.05 & 55.09 & 3.67 & 0.04 & 1.70 & 6.21 & 0.91 & 4.84 \\
\hline B4 & 36.5 & 0.16 & 35.41 & 56.16 & 8.28 & 0.04 & 2.17 & 24.77 & 1.51 & 8.06 \\
\hline $\mathrm{C} 1$ & 10.9 & 0.41 & 48.33 & 47.65 & 3.60 & 0.05 & 1.45 & 4.40 & 0.57 & 1.83 \\
\hline $\mathrm{C} 2$ & 19.0 & 0.13 & 35.91 & 55.80 & 8.16 & 0.04 & 2.05 & 5.60 & 1.10 & 3.80 \\
\hline $\mathrm{C} 3$ & 31.0 & 0.03 & 35.49 & 56.77 & 7.70 & 0.04 & 2.17 & 13.49 & 1.22 & 4.38 \\
\hline $\mathrm{C} 4$ & 42.0 & 0.13 & 26.25 & 63.03 & 10.60 & 0.04 & 2.37 & 12.53 & 0.89 & 4.12 \\
\hline D1 & 10.0 & 0.06 & 34.75 & 60.79 & 4.40 & 0.04 & 1.45 & 5.19 & 0.66 & 3.92 \\
\hline E1 & 7.0 & 45.24 & 40.59 & 13.37 & 0.80 & 5.82 & 3.59 & 19.07 & 0.05 & 2.77 \\
\hline E2 & 45.0 & 0.64 & 54.23 & 38.03 & 7.10 & 0.11 & 2.68 & 3.11 & 0.67 & 5.39 \\
\hline E3 & 54.0 & 0.04 & 16.59 & 69.18 & 14.20 & 0.03 & 2.30 & 6.14 & 1.19 & 4.36 \\
\hline F1 & 53.0 & 0.07 & 20.22 & 65.70 & 14.00 & 0.03 & 2.37 & 11.39 & 1.04 & 8.65 \\
\hline G1 & 39.0 & 24.36 & 47.34 & 23.60 & 4.70 & 0.84 & 3.65 & 24.48 & 0.90 & 4.82 \\
\hline G2 & 65.0 & 0.03 & 80.77 & 18.00 & 1.20 & 0.07 & 0.63 & 22.36 & 0.86 & 4.33 \\
\hline J1 & 37.0 & 1.36 & 39.36 & 49.32 & 9.96 & 0.04 & 2.25 & 19.51 & 0.73 & 2.67 \\
\hline $\mathrm{J} 2$ & 60.0 & 0.15 & 20.48 & 64.08 & 15.30 & 0.03 & 2.45 & 5.23 & 0.61 & 1.86 \\
\hline J3 & 70.0 & 0.13 & 26.32 & 59.66 & 13.89 & 0.03 & 2.37 & 14.85 & 0.87 & 4.08 \\
\hline
\end{tabular}

Minimum values for all the organic contaminants were recorded at Station A1, followed by Stations B1 and A2.

Mean ER-M and ER-L quotients were calculated separately based on the heavy metals and PAHs analyzed, for which sediment quality guidelines exist (Long et al., 1995) in order to estimate the potential of the contaminant to cause effects on the marine sediment biota and to compare it with the nematode response.

Considering heavy metals, Stations C2 and D1 presented a mean ER-Mq $>1.0$, indicating a relatively high probability of adverse biological effects, whilst Stations B3, C1, C3, E3, J1, J2 and J3 showed a mean ER-Mq $>0.5$, indicating a medium to high probability of biological adverse effects; all the other stations had a mean ER-Mq between 0.11 and 0.5 , indicating a low to medium risk (Long and MacDonald, 1998). All stations, excepting Stations A1, A2 and G2, had a mean ER-Lq $>1$, indicating that $86 \%$ of the stations had sediments with metals concentrations having the potential to cause adverse effects in sensitive species.

Considering PAHs, Stations B3, C1, C2, D1 and J1 presented a mean ER-Mq $>0.5$, indicating a medium to high probability of biological adverse effects due to organic chemicals, whilst Stations A1, A2 and G2 mean ER-Mq was $<0.1$, indicating a low risk; all the remaining stations presented a mean ER-Mq between 0.11 and 0.5 , indicating a low to medium probability of adverse biological effects. Stations B2, B3, C1, C2, C3, D1, E1, F1, G1, J1, J2 and J3 had a mean ERLq $>1$, indicating that $55 \%$ of the stations had sediments with the potential to cause adverse effects in sensitive species due to organic chemicals.

Table 2

Summary statistics of different contaminants with ER-L (Effect Range-Low) and ERM (Effect Range-Median) values reported for the sediment guidelines of USEPA by Long et al. (1995). n.d., not determined.

\begin{tabular}{lcclllll}
\hline & $\begin{array}{l}\text { PAHs } \\
\left(\mu \mathrm{kg}^{-1}\right)\end{array}$ & $\begin{array}{l}\mathrm{C}>12 \\
\left(\mu \mathrm{gg}^{-1}\right)\end{array}$ & $\begin{array}{l}\mathrm{As} \\
(\mathrm{ppm})\end{array}$ & $\begin{array}{l}\mathrm{Cd} \\
(\mathrm{ppm})\end{array}$ & $\begin{array}{l}\mathrm{Hg} \\
(\mathrm{ppm})\end{array}$ & $\begin{array}{l}\mathrm{Pb} \\
(\mathrm{ppm})\end{array}$ & $\begin{array}{l}\mathrm{Zn} \\
(\mathrm{ppm})\end{array}$ \\
\hline Mean & 2500 & 8100 & 22.86 & 0.23 & 0.90 & 75.41 & 271.82 \\
S.d. & 2160 & 8120 & 5.73 & 0.82 & 0.88 & 24.96 & 117.37 \\
Min & 150 & 2000 & 11.00 & 0.05 & 0.05 & 37.00 & 105 \\
Max & 8010 & 31,200 & 34.00 & 3.90 & 3.40 & 128.00 & 623 \\
Median & 1790 & 5350 & 23.00 & 0.05 & 0.55 & 75.00 & 237.50 \\
ER-L & 4020 & n.d. & 8.2 & 1.2 & 0.15 & 46.7 & 150 \\
ER-M & 44,790 & n.d. & 70 & 9.6 & 0.71 & 218 & 410 \\
\hline
\end{tabular}

Depth, sediment grain size, total organic matter quantity and biochemical composition were not correlated with contaminant concentrations and did not significantly influence their distribution, with the sole exception of Pb content, which showed significant $(p<0.05)$ positive correlations with silt and clay\% and Prt and a negative correlation with grain size (Appendix A).

\subsection{Nematode assemblages}

Univariate nematode measures are shown in Fig. 3. Mean nematode abundance ranged between $343.67 \pm 17.72$ ind $10 \mathrm{~cm}^{-2}$ (Station C2) and $4598.18 \pm 17.81$ ind $10 \mathrm{~cm}^{-2}$ (Station E3), representing a reduction with increasing $C>12$ values $(p<0.05)$ (Appendix A). The lowest number of genera was found at Station C2 $(16 \pm 9.90)$, the lowest diversity $(2.35 \pm 0.09)$ and evenness $(0.58 \pm 0.00)$ at Station B1. The highest number of genera $(38 \pm 1.41)$ and diversity $(4.79 \pm 0.03)$ were recorded at Station G2 while the highest evenness $(0.93 \pm 0.03)$ at Station C4. The number of genera, diversity and evenness increased strongly $(p<0.001)$ with increasing depth; positive correlations with TOM and Cho and negative with sorting were also detected $(p<0.05)$. The number of genera was also positively correlated with clay\% and negatively with $\mathrm{C}>12(p<0.05)$ (Appendix A).

ITD ranged from a minimum (maximum trophic diversity) of $0.30 \pm 0.02$ (Station F1) to a maximum (minimum trophic diversity) of $0.61 \pm 0.04$ (Station B1). The dominant trophic group was represented by non-selective deposit feeders (1B) (44\%), followed by epistrate feeders (2A) (28\%) and selective deposit feeders (1A) (23\%); predators/omnivores (2B) was the least dominant feeding type, with mean relative abundances of $4 \%$ (Fig. 4 ).

ITD showed a significant $(p<0.001)$ pattern of increase with increasing depth. Cho $(p<0.01)$, TOM, Prt and clay\% were also positively related $(p<0.05)$ with ITD, whilst sorting coefficient showed the opposite trend $(p<0.01)$ (Appendix A).

MI ranged between $2.36 \pm 0.09$ (Station C2) and $2.80 \pm 0.02$ (Station B1) due to the clear dominance of c-p 2 (mean relative abundance: $50 \%$ ) or c-p 3 (mean relative abundance: $41 \%$ ) genera (Fig. 4). By contrast, c-p 4 genera occurred at relatively low densities (mean relative abundance of $9 \%$ and a peak value of $21 \%$ at J3), while c-p 5 genera never occurred (Fig. 4). MI values were negatively affected by hydrocarbon concentrations and toxic potential 

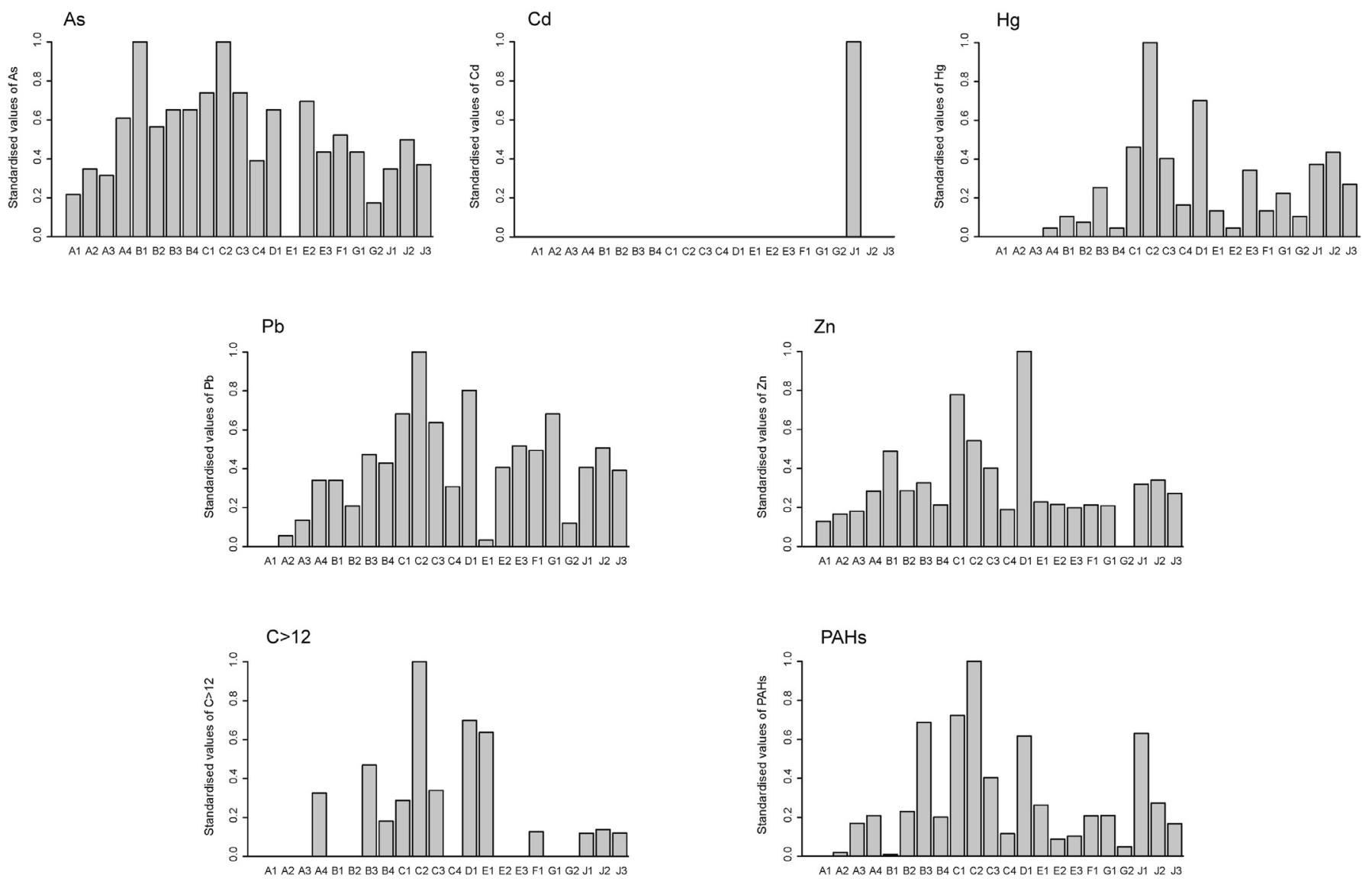

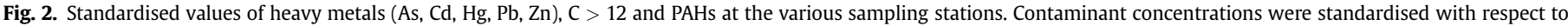
their minimum and maximum values.

$(p<0.05)$ but not by depth or sediment properties. $\mathrm{C}-\mathrm{p} 2$ group was positively related to hydrocarbons concentrations and toxic potential and TOM $(p<0.05)$, c-p 3 negatively to TOM $(p<0.001)$ and depth $(p<0.05)$; $c-$ p 4 positively to depth, $(p<0.001)$, TOM, Cho, clay\% $(p<0.05)$ and negatively to sorting $(p<0.01)$ (Appendix A).

Of the 128 genera found (Appendix B), Richtersia and Daptonema were the most abundant and frequent, occurring in all samples: Richtersia with mean relative abundances of $14 \%$ ( $\max =60 \%)$ and Daptonema with $13 \%$ ( $\max =34 \%$ ). The other genera present at all stations were Sabatieria (mean abundance $=7 \%$, $\max =33 \%$ ), Setosabatieria (mean abundance $=4 \%, \max =19 \%$ ) and Microlaimus (mean abundance $=4 \%, \max =19 \%$ ).

\subsection{Relationships between nematode assemblages and environmental variables}

The canonical correspondence analyses (CCA) accounted for $83 \%$ of the total variability, with the first axis (eigenvalue: 0.3931; $p=0.010$ ) accounting for approximately $23 \%$ of the constrained variability and the second axis (eigenvalue: $0.2257 ; p=0.005$ ) still accounting for $14 \%$. The Monte Carlo test revealed a significant correlation between the environmental variables gradient and the nematode genera $(p=0.005)$. CCA1 seems to separate the stations according to a gradient mainly determined by depth $(r=0.81)$, organic content $\left(r_{\mathrm{Cho}}=0.76 ; r_{\mathrm{Prt}}=0.71, r_{\mathrm{TOM}}=0.70\right)$ and, even to a lesser extent, also by sand and clay content $\left(r_{\text {sand }}=-0.61\right.$; $\left.r_{\text {clay }}=0.56\right)$. CCA2 seems to separate the stations according to a gradient of decreasing contamination $\left(r_{\mathrm{C}>12}=-0.83 ; r_{\mathrm{PAHs}}=-0.67\right.$; $\left.r_{\mathrm{Zn}}=-0.43\right)$ with all the vectors of the contaminants falling in the same quadrant (Fig. 5). The constrained ordination plot showed a clear separation of three main groups of stations (Figs. 5 and 6 ):

Group 1 (Stations A1, A2, B1 and B2): containing the stations located at the north-east of the harbour, presenting shallow, most sandy habitats, characterized by low contaminants and organic matter content. Chromadorita, Chaetonema, Marylynnia, Belbolla and Enoplolaimus resulted the genera most strongly associated to these conditions.

Group 2 (Stations A3, A4, B3, B4, C1, C2, C3, D1, E1 and J1): containing mostly the stations situated in close proximity to the harbour (with the exception of Station J1) with high levels of contamination, shallow to intermediate depth environments and a large gradient in substrate type (with sediments varying from medium silt to very coarse sand). Terschellingia, Comesa, Oncholaimellus, Sabatieria, Thalassoalaimus, Spirinia, Neotonchus, Microlaimus, Ptycholaimellus, Daptonema, Eleutherolaimus and Molgolaimus resulted the genera most strongly associated to these conditions.

Group 3 (Stations C4, E2, E3, F1, G1, G2, J2 and J3): containing the stations to the east-southeast of the harbour, presenting the deepest stations, intermediate contaminant concentrations, high quantities of organic matter, with high clay content and a large gradient in substrate type (with sediments classified from medium silt to very fine sand). These conditions were associated with the presence of many different genera, among which the most representative resulted Dorylaimopsis, Metacyatholaimus, Pierrickia, Diplopeltoides, Leptolaimus, Halalaimus, Pselionema, Desmoscolex, Sphaerolaimus, Rhips, Gnomoxyalia, and Tricoma.

Concerning univariate measures, Group 1 exhibited the lowest values of diversity, evenness and trophic diversity, the highest 


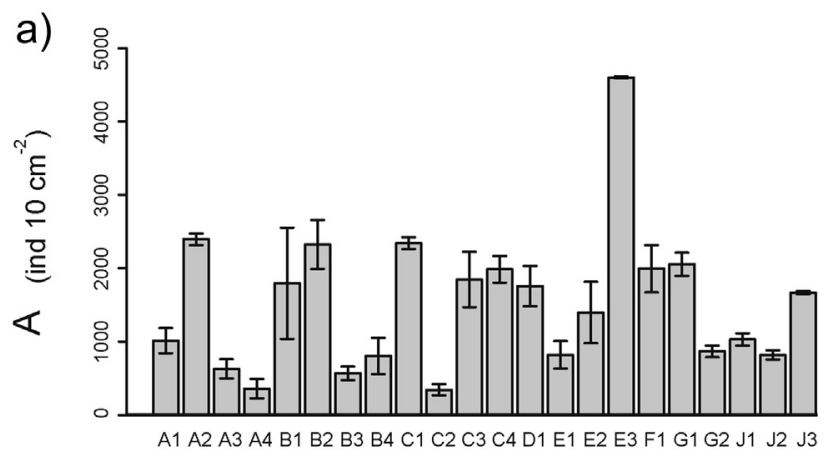

b)

$\omega$

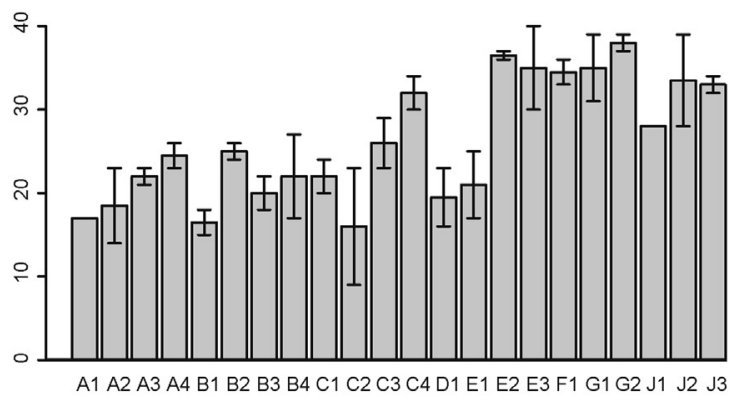

c)

d)
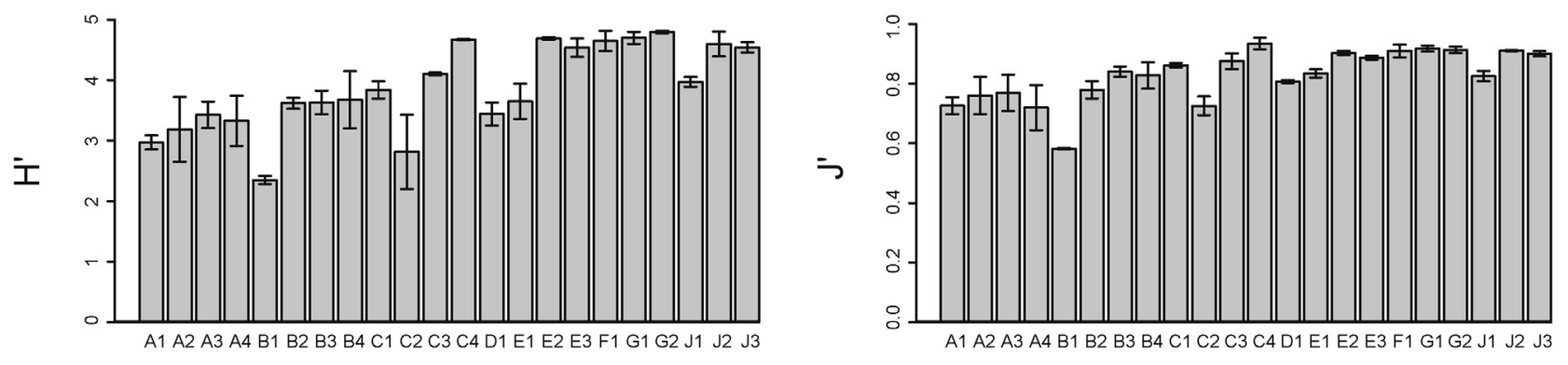

e)

f)
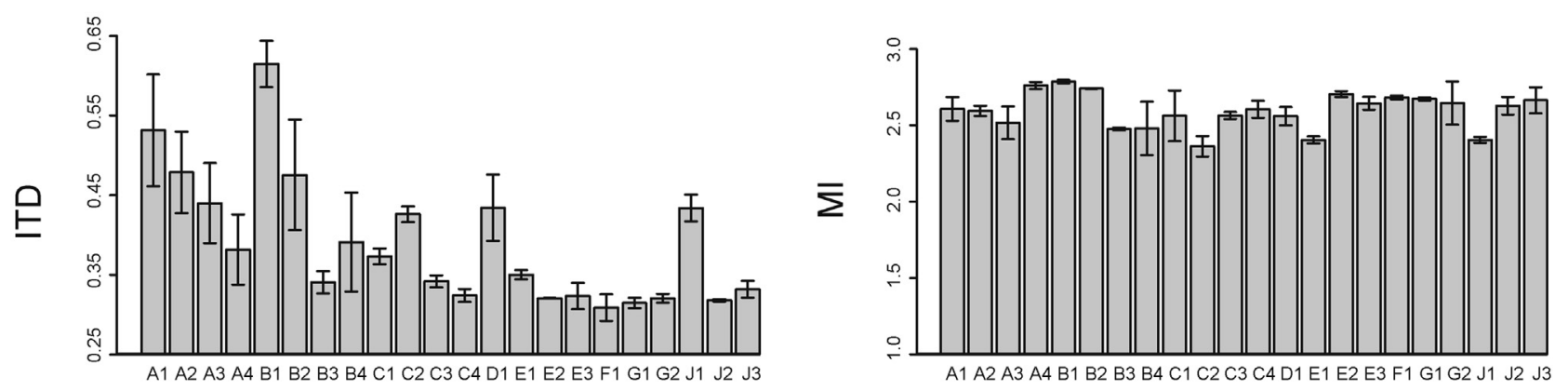

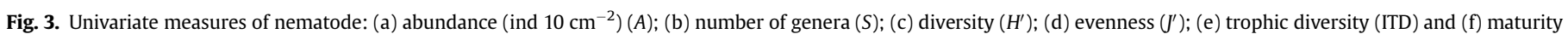
index (MI) at the various sampling stations.

abundances of $\mathrm{c}-\mathrm{p} 3$ genera, predominant at all the stations, and the lowest abundances of $\mathrm{c}-\mathrm{p} 2$ genera. Non-selective deposit feeders were highly dominant at all Group 1 stations (on average $65 \%$ ); followed by epistrate feeders (27\%), while predator/omnivores and selective deposit feeders showed low percentage dominance (5\% and 3\% respectively). Group 2 was characterized by the lowest nematode abundances and MI values, the latter due to the dominance of $\mathrm{c}-\mathrm{p} 2$ genera. Non-selective deposit feeders were the dominant trophic group at almost all stations (on average 47\%), followed by epistrate feeders (28\%) and selective deposit feeders (22\%), while dominance of predator/omnivores was low (3\%). Group 3 was characterized by assemblages with variable genus composition and the highest number of genera, diversity, evenness and trophic diversity; on average the selective deposit feeders were the most abundant (35\%), but similar percentages of non-selective deposit feeders (30\%) and epistrate feeders (28\%) were recorded; it also showed the highest percentage of predator/omnivores (6\%) and the highest abundance of $\mathrm{c}-\mathrm{p} 4$ genera.

DISTLM forward analysis revealed that most of the variance in nematode assemblage structure (63\%) was explained by depth, C > 12, ER-Lq Met, sorting, Prt and PAHs (Table 3).

The groups of environmental samples in the PCA ordination (Fig. 7) based on the environmental variables that best explained variation in nematode community structure (see Table 3 ) showed a remarkable similarity with groups identified in the CCA plot (cf. Figs. 7 and 5), suggesting that such variables were highly influential in determining genus distribution patterns. The PCA showed that the sampling sites differed mainly in terms of pollution and, to a lesser extent, in physical characteristics, food availability and sedimentological properties. PC1, explaining $46 \%$ of the variance, represented an axis of decreasing contaminant level: high negative values along PC2 were coupled with high PAHs, ER-Lq Met and 
a) $1 \mathrm{~A} \quad \square 1 \mathrm{~B} \quad \square 2 \mathrm{~A} \quad \square 2 \mathrm{~A}$

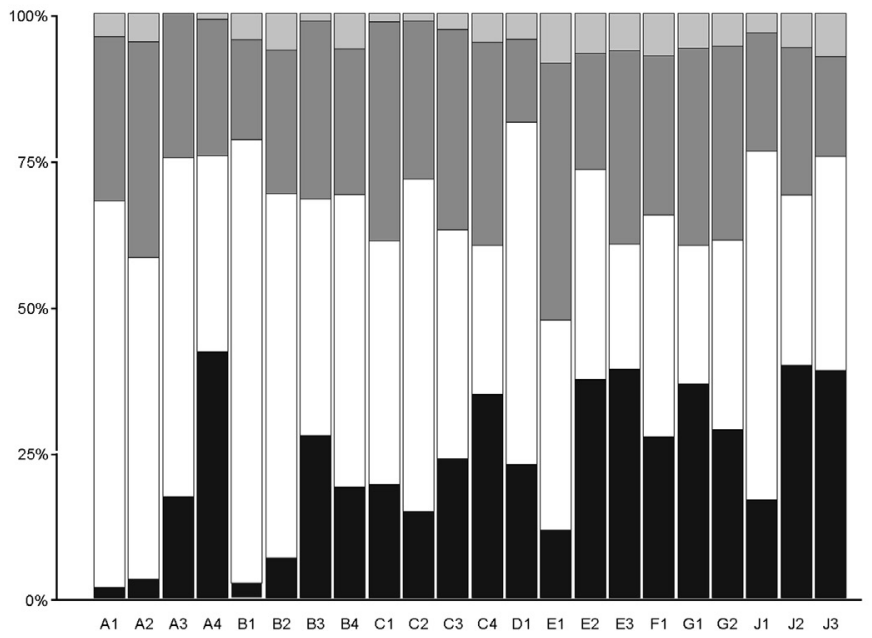

b)

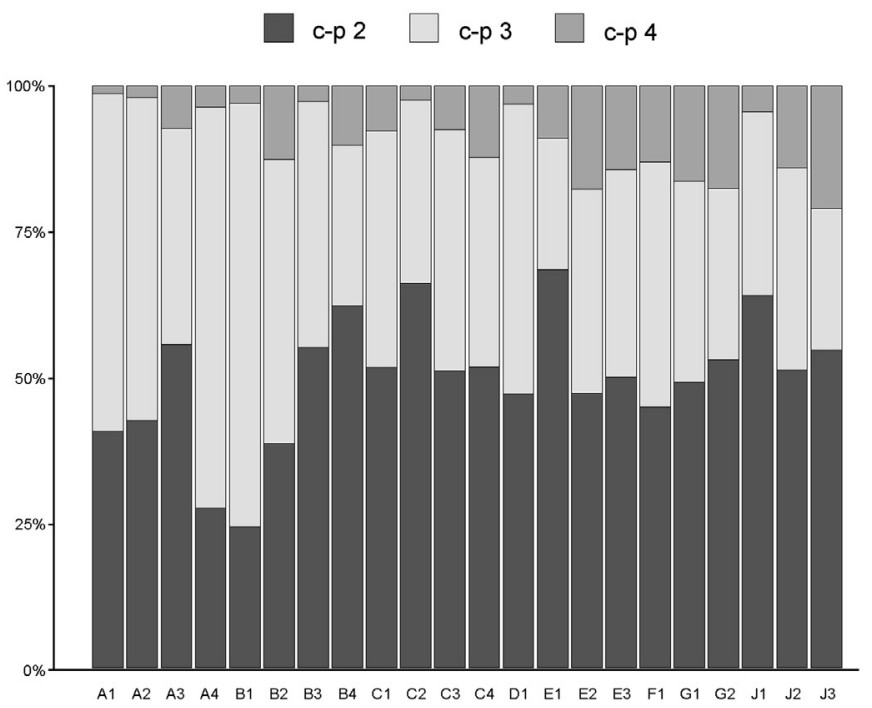

Fig. 4. Percentage of nematode: (a) trophic groups and (b) $c-p$ values at the various sampling stations.

C > 12 values. PC2, accounting for $28 \%$ of the variance, was driven by depth, Prt and sorting.

Results from both the statistical analyses and ordinations suggested that contaminant concentrations, depth, organic matter quantity and biochemical composition, and sediment composition were all important in explaining the variability in nematode assemblages. The information obtained by CCA relating individual genera with particular environmental variables were also confirmed by the Spearman's Rank Correlation Analysis results (Appendix A).

\section{Discussion}

The coastal area surveyed proved to be heterogeneous in terms of bathymetry, sedimentary parameters, organic loading and anthropogenic inputs. The comparison of contaminant levels with reference values (Long et al., 1995) indicated relatively high concentrations, especially for heavy metals, with sediments at a high number of stations having the potential to cause adverse effects in sensitive species. Concentrations of both heavy metals and PAHs were similar to ones reported in previous studies conducted in the area (Bertolotto et al., 2003a,b; Bertolotto et al., 2005). Other than the positive correlation between $\mathrm{Pb}$ concentrations and fine fractions, the remaining heavy metals showed no link with grain size, suggesting the relative importance of point sources in determining their distribution. The fact that even C $>12$ and PAHs, strongly hydrophobic chemicals with affinity for fine-grained sediments, showed no correlation with fine sediment particles, may indicate that, as for metals, their concentrations were driven by the relative size and location of the sources rather than by sediment composition. Some of the highest contaminant concentrations corresponded with stations located near the urban centre of Vado Ligure,
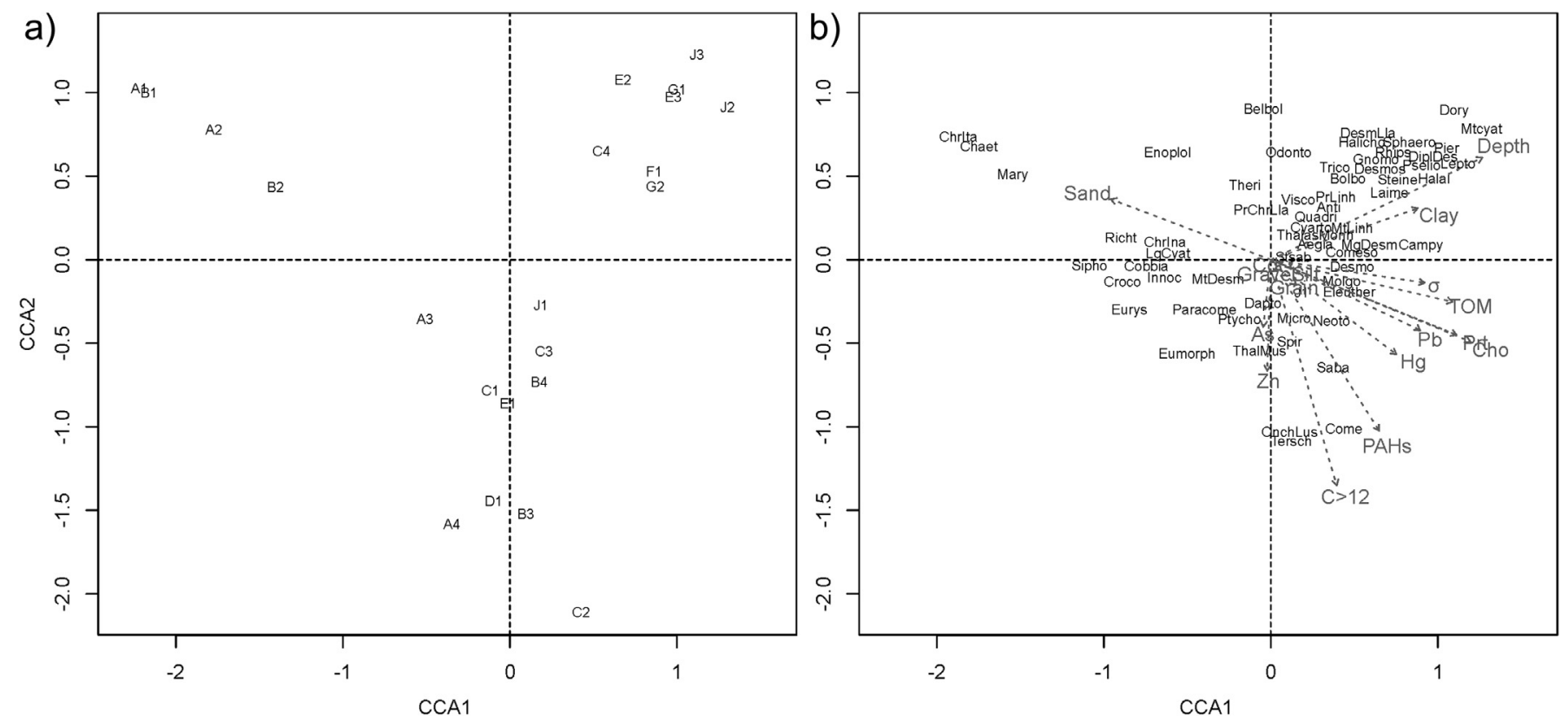

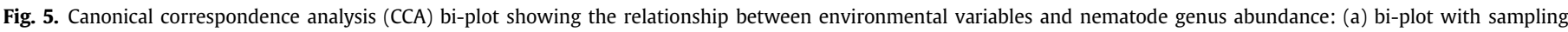
stations; (b) bi-plot with genera and environmental variables. For clarity, only genera with frequency $>0.1 \%$ are displayed; genera abbreviations as in Appendix B. 


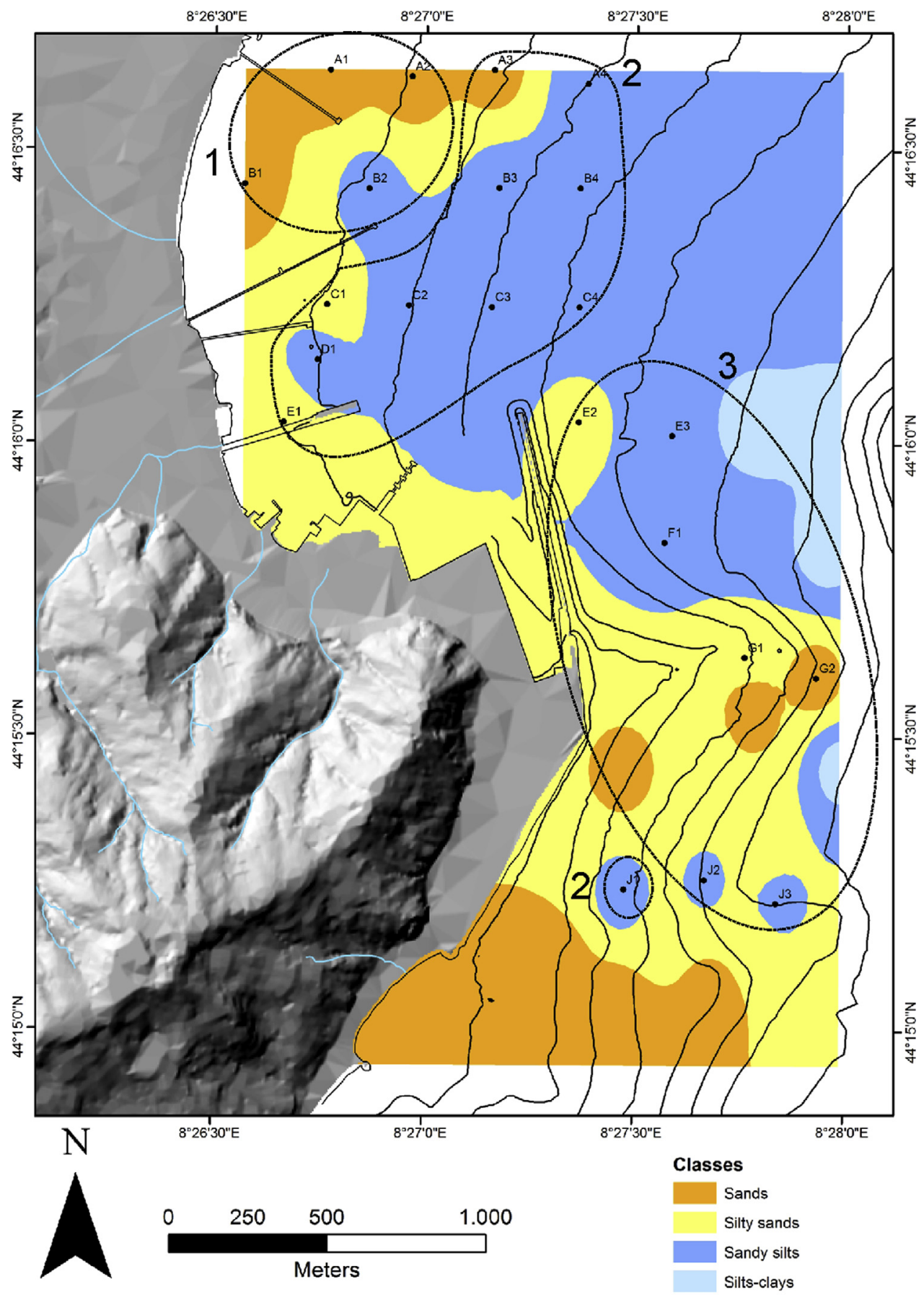

Fig. 6. Map of the study area superimposed with the three groups of stations identified by CCA ordination.

in close proximity to the harbour. This area is critical as a focus for the impact of the habour and its activities, being subject to the passage of ferries, holiday cruisers and container ships and situated close to a large coal-fuelled electricity generating plant, refineries, the production of bitumen and tar and also to the mouths of the Segno, Quiliano and Letimbro, streams that pass through a densely populated and industrialized area.

One of the aims of the present study was to test whether there was a relationship between the observed patterns of nematode abundance, diversity and assemblage structure and the main environmental variables and human influences. Across the study area, $63 \%$ of the variation in nematode assemblages, was explained by six environmental variables, suggesting a strong link between nematode assemblage structure and depth, contamination, food availability and sediment characteristics. This was confirmed by the high similarity between the distribution of stations in ordinations based on both PCA of environmental variables data and CCA of nematode genus abundance data. The PCA showed that the sampling stations were differentiated mainly by concentrations of hydrocarbons and heavy metals, with depth, organic load and sediment proprieties also identified as secondary differentiating factors. The differences in nematode community structure identified three groups of stations which could be differentiated by differences in bathymetric and physico-chemical properties. In the 
Table 3

Results of the multivariate multiple regression analysis of nematode composition on individual environmental variables for forward selection of variables, where amount explained by each variable added to model is conditional on variables already in the model.

\begin{tabular}{cllllll}
\hline & Variable & SS & $F$ & $P$ & \% var & \% cum \\
\hline Nematode genera & Depth & 9143.4 & 6.5 & $\mathbf{0 . 0 0 1}$ & 24.5 & 24.5 \\
composition & C > 12 & 5497.9 & 4.7 & $\mathbf{0 . 0 0 1}$ & 15.0 & 39.5 \\
& ER-Lq Met & 2371.4 & 2.3 & $\mathbf{0 . 0 0 9}$ & 6.4 & 45.9 \\
& Sorting & 2314.2 & 2.2 & $\mathbf{0 . 0 0 5}$ & 6.3 & 52.2 \\
& Prt & 2149.1 & 2.2 & $\mathbf{0 . 0 0 9}$ & 5.8 & 58.0 \\
& PAHs & 1869.7 & 2.0 & $\mathbf{0 . 0 0 5}$ & 5.0 & 63.0
\end{tabular}

Reported are only the variables that contribute significantly to explain percentage of explained variance (SS, sum of squares; $F, F$-statistic; $P$, probability level; \% var, percentage of variance in multivariate data explained by that variable; \% cum, cumulative percentage of variance explained).

CCA, depth, organic contaminants and organic content were shown to be the variables with the strongest correlation, indicating their importance in structuring nematode assemblages in the survey area.

DISTLM analysis showed that, although factors related to sedimentary conditions and food proprieties were important, the highest portion of nematode variability was explained by contaminants (cumulative: $26 \%$ ) and depth (24\%). This result is very significant, since usually, in non-impacted environments, sediment grain size represents the 'super factor' in determining meiobenthic community structure (Platt et al., 1984).

The influence of hydrocarbons and heavy metals on nematode assemblages has been shown by many authors in both field and microcosm studies (e.g., Giere, 1979; Renaud-Mornant et al., 1981; Danovaro et al., 1995; Austen and Somerfield, 1997; Danovaro et al., 1999; Beyrem et al., 2007; Heininger et al., 2007; Boufahja et al., 2011a). As well as their direct effects on nematode assemblages, hydrocarbons also appear to influence nematodes indirectly through effects on sediments such as dissolved oxygen depletion and changes in sediment proprieties (Mahmoudi et al., 2005 and refs therein), while the accumulation of heavy metals in sediments may alter associated microbial communities which may influence the meiobenthos through alterations in food supply (Austen and McEvoy, 1997). Moreover, the combination of heavy metals and hydrocarbons could be additive or even synergistic. Beyrem et al. (2007) reported that if a low dose of diesel alone didn't affect nematode abundances, a diesel-metal combination may cause significant abundance decreases. Diesel induced higher production

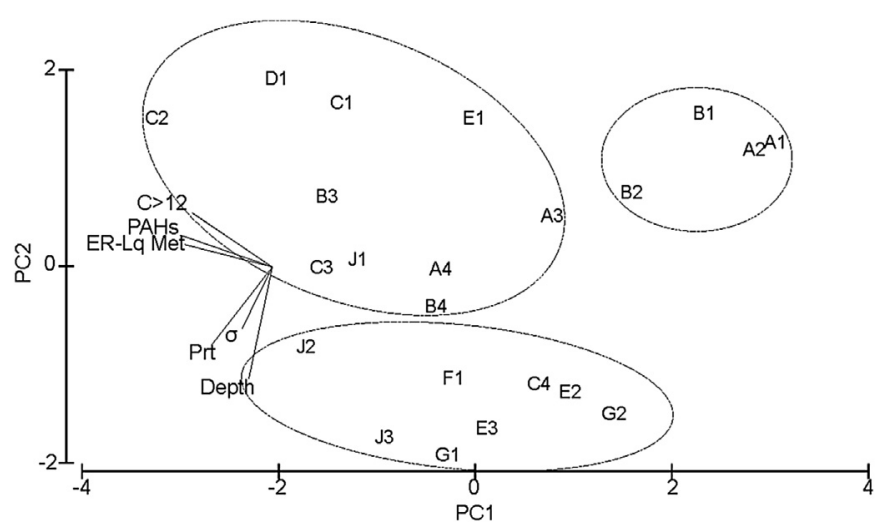

Fig. 7. PCA ordination (including variable vectors) based on normalized environmental data (all concentrations were log-transformed). Variables shown in the ordination were those that best explained variation in nematode assemblage structure (see Table 3). Superimposed clusters are the three station groups identified by CCA ordination. of mucus-exopolymers from algal blooms, typical of dieselcontaminated sediments, which have a strong affinity for several metals and were subsequently consumed by benthic organisms, increasing their exposure to metals (Beyrem et al., 2007 and refs therein). Changes in nematode assemblage structure, mortality of the most sensitive species and diversity reduction have been reported by several authors as typical effects of exposure to heavy metals and hydrocarbons contamination (e.g., Boucher, 1980; Tietjen, 1980; Somerfield et al., 1994; Danovaro et al., 1995; Austen and Somerfield, 1997; Beyrem and Aïssa, 2000; Mahmoudi et al., 2002; Hedfi et al., 2007, 2008; Boufahja et al., 2011a). Nematode abundance may not be affected, but many studies have reported significant decrease in nematode abundance due to heavy metals (e.g., Mahmoudi et al., 2002, 2007; Hedfi et al., 2007, 2008; Hermi et al., 2009; Beyrem et al., 2011; Gyedu-Ababio, 2011; Boufahja et al., 2011a) or hydrocarbons (e.g., Giere, 1979; Danovaro et al., 1995, 1999; Beyrem and Aïssa, 2000; Mahmoudi et al., 2002, 2005; Beyrem et al., 2010).

In the present study, the nematode univariate measures of abundance, number of genera and maturity index were negatively affected by hydrocarbons. The multivariate structure of nematode assemblages revealed three groups of stations clearly differentiated by their contamination level. The differences in nematode genus composition between these groups were also reflected in their lifehistory strategies (c-p values) and feeding type. In particular Group 2 , which was characterized by lower abundance and MI values as well as the highest percentage of opportunistic (c-p 2) genera, could be distinguished from the other two groups by its higher level of contamination, whilst its sediments were heterogeneous in terms of grain size and organic load. Among its stations, Station C2 was the most affected by pollution, with highest values of PAHs, $\mathrm{C}>12, \mathrm{As}, \mathrm{Hg}, \mathrm{Pb}$, ER-Lq Met, ER-Mq Met and ER-Lq PAHs. It was dominated by Sabatieria, Daptonema, Comesa and Terschellingia and showed the lowest nematode abundance, MI value and number of genera and some of the lowest values of diversity and evenness.

Depth, organic matter quantity and composition and sedimentological proprieties, are also factors that can modify the effects of pollutants (e.g. Tietjen, 1980), and were significant in explaining observed nematode distributions and distinguishing Group 1 and Group 3, which had lower contamination levels than Group 2.

Variations in natural sediment proprieties, such as grain size, silt/clay content and sorting, are known to influence the nematode assemblages (Platt et al., 1984; Heip et al., 1985; Vanreusel, 1990; Schratzberger et al., 2006; Semprucci et al., 2010). Another important factor influencing benthic assemblages is food availability (Montagna et al., 1983; Rudnick et al., 1985) and in particular the utilizable fraction of the organic pool (i.e. labile compounds such as proteins and carbohydrates, Fabiano et al., 1995).

Depth is a common correlate of assemblage structure, most likely because it determines other factors such as the amount and nature of phytoplankton-derived food reaching the benthos and the stability of physico-chemical factors (Guo et al., 2001; Schratzberger et al., 2006). In our study area, depth was also positively related to fine sediment fraction, organic load and food availability (proteins and carbohydrates).

Group 1 was characterized by lower TOM, Prt and Cho compared with the other groups. As an indicator of potential food limitation at these stations, this may explain the low diversity and high dominance found, despite the relatively low levels of contamination. Certainly, the genera found at these stations showed the highest and lowest percentages of $\mathrm{c}-\mathrm{p} 3$ and $\mathrm{c}-\mathrm{p} 2$ types respectively, reflecting the low levels of contamination.

Group 3, having an intermediate degree of contamination defined by medium to low contaminant content, was characterized by stations with high quantities of TOM, Prt and Cho and greater 
depths. These stations showed higher diversity and persister nematodes ( $\mathrm{c}-\mathrm{p} 4) \%$. Nematode assemblages at these stations also showed a different trophic strategy, with dominance of selective deposit feeders and the highest \% of predators/omnivores. At these stations, higher food availability and diversity, coupled with higher sediment stability associated with reduced wave disturbance at deeper sampling stations, resulted in a more stable and diverse assemblage. Also significant could be the role of contaminant bioavailability. The bioavailability and, therefore, the toxicity of a contaminant depends on its partitioning between the sediment, pore water, and overlying water (Austen and McEvoy, 1997), which can also be dependent on the sediment organic carbon content ( $\mathrm{Di}$ Toro et al., 1991). In fact highly lipophilic chemicals are probably bound to organic carbon and as such are not directly bioavailable for the biota (Liu et al., 2004), therefore there is a greater toxic effect of these contaminants in sediments with low organic content since the free ions in water are the most bioavailable. This may explain why in this study the effect of contaminants was low in the group of stations with high organic carbon content in the sediments and even in the stations with higher contaminant concentrations (Stations $\mathrm{J} 2$ and $\mathrm{J} 3$ ).

Another aim of the study was to evaluate the potential of nematodes as pollution indicators investigating whether there were nematode genera which could be reliably used as indicators of pollution or environmental quality.

There is much evidence that to be successful, pollution assessment may not have to be conducted at the species level (Warwick, 1988; Danovaro et al., 1995) and that pollution effects are detectable at even higher taxonomic levels (Warwick, 1988). Moreno et al. (2011) in a study evaluating the use of nematodes as biological indicators of sediment environmental quality at many different sites in the Mediterranean Sea, compared the use of different ecological indices, including $H^{\prime}, \mathrm{MI}, \mathrm{c}-\mathrm{p} \%$, ITD and presence of sensitive/tolerant genera and found that the latter proved to be the best tool for efficient evaluation of ecological quality status.

In the present study the analysis of nematode assemblages at the genus level was the most informative tool as well, showing a high correspondence with the environmental variables and with pollution in particular.

The results of the CCA analysis identified a number of genera which appeared to be tolerant to hydrocarbon and metal contamination including Sabatieria, Terschellingia, Comesa, Oncholaimellus, Microlaimus, Molgolaimus, Daptonema, Ptycholaimellus, Spirinia, Eleutherolaimus, Neotonchus and Thalassoalaimus.

These results agreed with many studies. Sabatieria is a genus widely recognized as tolerant to pollution and able to persist under conditions that are unsuitable for most other nematode species (e.g., Tietjen, 1980; Somerfield et al., 1994; Austen and Somerfield, 1997; Schratzberger et al., 2006; Armenteros et al., 2009). Terschellingia is also a genus considered tolerant to metal and hydrocarbons contamination (e.g., Somerfield et al., 1994; Austen and Somerfield, 1997; Armenteros et al., 2009; Beyrem et al., 2010). Molgolaimus, a genus often associated to reduced conditions (Van Gaever et al., 2004), and Ptycholaimellus were found to be tolerant to a wide range of metal concentrations both in field and microcosm studies (Somerfield et al., 1994; Austen and Somerfield, 1997), and Microlaimus to heavy metals (Gyedu-Ababio and Baird, 2006). Moreover, Microlaimus is considered a successful, fast and opportunistic colonizer (Van Gaever et al., 2009) as well as Molgolaimus, another opportunistic colonizer abundant under stressful conditions and in recently colonized sediments (Fonseca et al., 2006, 2007). Daptonema is known as an opportunistic genus in relation to heavy metals (e.g., Millward and Grant, 1995; Hedfi et al., 2007; Boufahja et al., 2011a) and hydrocarbons (Mahmoudi et al., 2005). Eleutherolaimus showed a reduced sensitivity to heavy metals (Millward and Grant, 1995) while Spirinia was resistant to oil contamination (Beyrem et al., 2010) and was found to be among the dominant genera in an experiment on muddy polluted sediments (Armenteros et al., 2010). Oncholaimellus has shown high resilience to hydrocarbons contamination (Danovaro et al., 1995) and an opportunistic response to various heavy metals (Hedfi et al., 2007; Mahmoudi et al., 2007), but also sensitivity to metals (Beyrem et al., 2011), therefore its use as indicator of contamination is critical. These controversial responses could be related to the fact that, although Oncholaimidae have a high $\mathrm{c}-\mathrm{p}$ score on the MI scale, due to their slow growth and reproduction, they may have a high colonization ability in situations of organic enrichment or stress (e.g., anoxia) in which they can accumulate mono-populations (Somerfield et al., 2003; Neher and Darby, 2006).

Genera found to be sensitive to metals and hydrocarbons according to CCA analysis included Chaetonema, Marylynnia, Chromadorita, Belbolla, and Enoplolaimus. Chaetonema has been reported to be intolerant to diesel (Mahmoudi et al., 2005) and permethrin (Boufahja et al., 2011b), while Chromadorita was one of the genera that decreased after the "Amoco Cadiz" spill (Boucher, 1980). Marylynnia is reported to be resistant in microcosm experiments with diesel (Mahmoudi et al., 2005) and opportunistic in experiments with $\mathrm{Hg}$ (Hermi et al., 2009), but seems to be sensitive to the hydrocarbon and metal combination (Beyrem et al., 2007). Enoplolaimus, a predator, probably slow growing, has been found to be sensitive to copper in both microcosm and field studies (Lee and Correa, 2004; Hedfi et al., 2008) despite becoming dominant after the La Coruña oil spill (Giere, 1979).

\section{Conclusions}

The pattern of nematode assemblages found in the study area was strongly related to environmental variables; contamination level, bathymetry, quantity and composition of organic matter and sediment proprieties. Anthropogenic effects were found on nematode abundance, number of genera and maturity index. The multivariate structure of the nematode assemblages was clearly related to the level of contamination of their sediments. In particular, the group of stations in the proximity of Vado Ligure city centre and its harbour were the most affected.

Analysis of nematode assemblages at the genus level was the most informative tool, showing high correspondence with the environmental variables and with pollution in particular. The use of a constrained ordination (CCA) allowed for discrimination of the effects of contaminants on nematode genera from those of other environmental variables. In particular, it resulted in the identification of a suite of genera for their tolerance or sensitivity to contaminants which could be important in the future evaluation of environmental quality status.

\section{Acknowledgments}

This work was partially done within the frame of the research agreement between DISTAV and CIMA Research Foundation. The authors are grateful to CIMA Research Foundation for scientific cooperation. We also thank the staff of the Laboratory of Ecology (University of Genoa) for precious help with laboratory analyses, and Mariachiara Chiantore and Luigi Vezzulli for valuable suggestions. Special thanks go to the two anonymous referees for their constructive and critical reviews of the manuscript.

\section{Appendix A. Supplementary data}

Supplementary data related to this article can be found at http:// dx.doi.org/10.1016/j.ecss.2013.02.017. 


\section{References}

Armenteros, M., Pérez-Angul, A., Regadera, R., Beltrán, J., Vincx, M., Decraemer, W., 2009. Effects of chronic and heavy pollution on macro- and meiobenthos of Havana Bay, Cuba. Revista de Investigaciones Marinas 30 (3), 203-214.

Armenteros, M., Pérez-García, J.A., Ruiz-Abierno, A., Díaz-Asencio, L., Helguera, Y., Vincx, M., Decraemer, W., 2010. Effects of organic enrichment on nematode assemblages in a mirocosm experiment. Marine Environmental Research 70 (5), 374-382.

Austen, M.C., McEvoy, A.J., 1997. The use of offshore meiobenthic communities in laboratory microcosm experiments: response to heavy metal contamination. Journal of Experimental Marine Biology and Ecology 211, 247-261.

Austen, M.C., Somerfield, P.J., 1997. A community level sediment bioassay applied to an estuarine heavy metal gradient. Marine Environmental Research 43, 315-328.

Bertolotto, R.M., Ghioni, F., Frignani, M., Alvarado-Aguilar, D., Bellucci, L.G., Cuneo, C., Picca, M.R., Gollo, E., 2003a. Polycyclic aromatic hydrocarbons in surficial coastal sediments of the Ligurian Sea. Marine Pollution Bulletin 46, 903-917.

Bertolotto, R.M., Tortarolo, B., Frignani, M., Bellucci, L.G., Albanese, S., Cuneo, C., 2003b. Heavy metals in coastal sediments of the Ligurian Sea off Vado Ligure. Journal de Physique IV France 107, 159-162.

Bertolotto, R.M., Tortarolo, B., Frignani, M., Bellucci, L.G., Albanese, S., Cuneo, C., Alvarado-Aguilar, D., Picca, M.R., Gollo, E., 2005. Heavy metals in surficial coastal sediments of the Ligurian Sea. Marine Pollution Bulletin 50, 348-356.

Beyrem, H., Aïssa, P., 2000. Les nématodes libres, organismes-sentinelles de l'évolution des concentrations d'hydrocarbures dans la baie de Bizerte (Tunisie). Cahiers de Biologie Marine 41, 329-342.

Beyrem, H., Boufahja, F., Hedfi, A., Essid, N., Aïssa, P., Mahmoudi, E., 2011. Laboratory study on individual and combined effects of cobalt- and zinc-spiked sediment on meiobenthic nematodes. Biological Trace Elements Research 144 (1-3), 790-803.

Beyrem, H., Louati, H., Essid, N., Aïssa, P., Mahmoudi, E., 2010. Effects of two lubricant oils on marine nematode assemblages in a laboratory microcosm experiment. Marine Environmental Research 69, 248-253.

Beyrem, H., Mahmoudi, E., Essid, N., Hedfi, A., Boufahja, F., Aïssa, P., 2007. Individual and combined effects of cadmium and diesel on a nematode community in a laboratory microcosm experiment. Ecotoxicology and Environmental Safety 68, 412-418.

Bongers, T., 1990. The maturity index: an ecological measure of an environmental disturbance based on nematode species composition. Oecologia 83, 14-19.

Bongers, T., Ferris, H., 1999. Nematode community structure as a bioindicator in environmental monitoring. Trends in Ecology and Evolution 14, 224-228.

Bongers, T., Alkemade, R., Yeates, G.W., 1991. Interpretation of disturbance induced maturity decrease in marine nematode assemblages by means of the Maturity Index. Marine Ecology Progress Series 76, 135-142.

Boucher, G., 1980. Impact of Amoco Cadiz oil spill on intertidal and sublittoral meiofauna. Marine Pollution Bulletin 11, 95-101.

Boufahja, F., Hedfi, A., Amorri, J., Aïssa, P., Beyrem, H., Mahmoudi, E., 2011a. An assessment of the impact of chromium-amended sediment on a marine nematode assemblage using microcosm bioassays. Biological Trace Elements Research 142, 242-255.

Boufahja, F., Sellami, B., Dellali, M., Aïssa, P., Mahmoudi, E., Beyrem, H., 2011b. A microcosm experiment on the effects of permethrin on a free-living nematode assemblage. Nematology 13 (8), 901-909.

Bruland, K.W., Bertine, K., Koide, M., Goldberg, E.D., 1974. History of metal pollution in Southern California coastal zone. Environmental Science and Technology 8 (5), 425-432.

Casazza, G., Silvestri, C., Spada, E., 2002. The use of bio-indicators for quality assessments of the marine environment: example from the Mediterranean sea. Journal of Coastal Conservation 8, 147-156.

Coull, B.C., Chandler, G.T., 1992. Pollution and meiofauna: field, laboratory and mesocosm studies. Oceanography and Marine Biology: An Annual Review 30, 191-271.

Danovaro, R., Fabiano, M., Vincx, M., 1995. Meiofauna response to the Agip Abruzzo oil spill in subtidal sediments of the Ligurian Sea. Marine Pollution Bulletin 30, 133-145.

Danovaro, R., Della Croce, N., Marrale, D., Martorano, D., Parodi, P., Pusceddu, A., Fabiano, M., 1999. Biological indicators of oil induced disturbance in coastal sediments of the Ligurian Sea. In: Lokman, S., Shazili, N.A.M., Nasir, M.S. Borowtizka, M.A. (Eds.), Assessment \& Monitoring of Marine Science. University Putra Malaysia Terengganu, Kuala Terengganu, Malaysia, pp. 75-85.

Di Toro, D.M., Zarba, C.S., Hansen, D.J., Berry, W.J., Cowan, C.E., Pavlou, S.P., Allen, H.E., Thomas, N.A., Paquin, P.R., 1991. Technical basis for establishing sediment quality criteria for nonionic organic chemicals using equilibrium partitioning. Environmental Toxicology and Chemistry 10, 1541-1583.

Dubois, M., Gilles, K., Mamilton, J.K., Rebers, P.A., Smith, F., 1956. Colorimetric method for determination of sugar and related substances. Analytical Chemistry $28,350-356$.

Fabiano, M., Danovaro, R., Fraschetti, S., 1995. A three-year time series of elemental and biochemical composition of organic matter in subtidal sandy sediment of the Ligurian Sea (NW Mediterranean). Continental Shelf Research $15,1453-1469$.

Fiscus, D.A., Neher, D.A., 2002. Distinguishing sensitivity of free-living soil nematode genera to physical and chemical disturbances. Ecological Applications 12, 565-575.
Fonseca, G., Muthumbi, A.W., Vanreusel, A., 2007. Species richness of the genus Molgolaimus (Nematoda) from local to ocean scale along continental slopes. Marine Ecology 28, 446-459.

Fonseca, G., Vanreusel, A., Decraemer, W., 2006. Taxonomy and biogeography of Molgolaimus Ditlevsen, 1921 (Nematoda: Chromadoria) with reference to the origins of deep sea nematodes. Antarctic Science 18 (1), 23-50.

Frontalini, F., Semprucci, F., Coccioni, R., Balsamo, M., Bittoni, P., Covazzi-Harriage, A., 2011. On the quantitative distribution and community structure of the meio and macrofaunal communities in the coastal area of the Central Adriatic Sea (Italy). Environmental Monitoring and Assessment 180, 325-344.

Gerchakov, S.M., Hatcher, P.G., 1972. Improved technique for analysis of carbohydrates in sediments. Limnology and Oceanography 17, 938-943.

Gerlach, S.A., 1971. On the importance of marine meiofauna for benthos communities. Oecologia (Berlin) 6, 176-190.

Giere, O., 1979. The impact of oil pollution on intertidal meiofauna. Field studies after the La Coruna spill, May, 1976. Cahiers de Biologie Marine 20, 231-251.

Guo, Y., Somerfield, P.J., Warwick, R.M., Zhang, Z., 2001. Large-scale patterns in the community structure and biodiversity of free living nematodes in the Bohai Sea, China. Journal of the Marine Biological Association of the United Kingdom 81, 755-763.

Gyedu-Ababio, 2011. Pollution status of two river estuaries in the Eastern Cape South Africa, based on benthic meiofauna analyses. Journal of Water Resource and Protection 3, 473-486.

Gyedu-Ababio, T.K., Baird, D., 2006. Response of meiofauna and nematodes to increased levels of contamination in a laboratory experiment. Ecotoxicology and Environmental Safety 63 (3), 443-450.

Haas, P.M., 1989. Do regimes matter? Epistemic communities and Mediterranean pollution. International Organization 43 (3), 377-403.

Hartree, E.F., 1972. Determination of proteins: a modification of the Lowry method that give a linear photometric response. Analytical Biochemistry 48 $422-427$.

Hedfi, A., Mahmoudi, E., Boufahja, F., Beyrem, H., Aïssa, P., 2007. Effects of increasing levels of nickel contamination on structure of offshore nematode communities in experimental microcosms. Bulletin of Environmental Contaminant and Toxicology 79, 345-349.

Hedfi, A., Mahmoudi, E., Beyrem, H., Boufahja, F., Essid, N., Aïssa, P., 2008. Réponse d'une communauté de nématodes libres marins à une contamination par le cuivre: étude microcosmique. Bulletin de la Société zoologique de France 133, 97-106.

Heininger, P., Höss, S., Claus, E., Pelzer, J., Traunspurger, W., 2007. Nematode communities in contaminated river sediments. Environmental Pollution 146, 64-76.

Heip, C., Vincx, M., Vranken, G., 1985. The ecology of marine nematodes. Oceanography and Marine Biology: An Annual Review 23, 399-489.

Hermi, M., Mahmoudi, E., Beyrem, H., Aïssa, P., Essid, N., 2009. Responses of a freeliving marine nematode community to mercury contamination: results from microcosm experiments. Archives of Environmental Contamination and Toxicology 56, 426-433.

Höss, S., Claus, E., Von der Ohe, P.C., Brinke, M., Güde, H., Heininger, P. Traunspurger, W., 2011. Nematode species at risk - a metric to assess pollution in soft sediments of freshwaters. Environment International 37, 940-949.

Kennedy, A.D., Jacoby, C.A., 1999. Biological indicators of marine environmental health: meiofauna - a neglected benthic component? Environmental Monitoring and Assessment 54, 47-68.

Lee, M.R., Correa, J.A., 2004. Copper mine tailings disposal: consequences for the interstitial polychaete Saccocirrus sonomacus (Canalipalpata: Protodrilida). Journal of the Marine Biological Association of the United Kingdom 84 603-606.

Liu, W.P., Gan, J.J., Lee, S., Kabashima, J.N., 2004. Phase distribution of synthetic pyrethroids in runoff and stream water. Environmental Toxicology and Chemistry $23,7-11$.

Long, E.R., MacDonald, D.D., 1998. Recommended uses of empirically derived sediment quality guidelines for marine and estuarine ecosystems. Human and Ecology Risk Assessment 4, 1019-1039.

Long, E.R., Field, L.J., MacDonald, D.D., 1998. Predicting toxicity in marine sediments with numerical sediment quality guidelines. Environmental Toxicology and Chemistry 17, 714-727.

Long, E.R., MacDonald, D.D., Smith, S.L., Calder, F.D., 1995. Incidence of adverse biological effects within ranges of chemical concentrations in marine and estuarine sediments. Environmental Management 19, 81-97.

Mahmoudi, E., Beyrem, H., Baccar, L., Aïssa, P., 2002. Response of free-living Nematodes to the quality of water and sediment at Bou Chrara Lagoon (Tunisia) during winter 2000. Mediterranean Marine Science 2, 133-146.

Mahmoudi, E., Essid, N., Beyrem, H., Hedfi, A., Boufahja, F., Vitiello, P., Aïssa, P., 2005 Effects of hydrocarbon contamination on a free living marine nematode community: results from microcosm experiments. Marine Pollution Bulletin 50 1197-1204.

Mahmoudi, E., Essid, E., Beyrem, H., Hedfi, A., Boufahja, F., Vitiello, P., Aïssa, P., 2007. Individual and combined effects of lead and zinc of a free living marine nematode community: results from microcosm experiments. Journal of Experimental Marine Biology and Ecology 343, 217-226.

Martínez-Lladó, X., Gibert, O., Martí, V., Díez, S., Romo, J., Bayona, J.M., de Pablo, J., 2007. Distribution of polycyclic aromatic hydrocarbons (PAHs) and tributyltin (TBT) in Barcelona harbour sediments and their impact on benthic communities. Environmental Pollution 149, 104-113. 
McArdle, B.H., Anderson, M.J., 2001. Fitting multivariate models to community data: a comment on distance-based redundancy analysis. Ecology 82, 290-297.

McCready, S., Slee, G.F., Birch, G.F., Taylor, S.E., 2000. The distribution of polycyclic aromatic hydrocarbons in surficial sediments of Sydney Harbour, Australia. Marine Pollution Bulletin 40, 999-1006.

Millward, R.N., Grant, A., 1995. Assessing the impact of copper on nematode communities from a chronically metal metal-enriched estuary using pollutioninduced community tolerance. Marine Pollution Bulletin 30, 701-706.

Montagna, P.A., Coull, C.B., Herring, T.L., Dudley, B.W., 1983. The relationship between abundances of meiofauna and their suspected microbial food (diatoms and bacteria). Estuarine, Coastal and Shelf Science 17, 381-394.

Montefalcone, M., Albertelli, G., Morri, C., Parravicini, V., Bianchi, C.N., 2009. Lega protection is not enough: Posidonia oceanica meadows in marine protected areas are not healthier than those in unprotected areas of the northwest Mediterranean Sea. Marine Pollution Bulletin 58, 515-519.

Moreno, M., Semprucci, F., Vezzulli, L., Balsamo, M., Fabiano, M., Albertelli, G., 2011 The use of nematodes in assessing ecological quality status in the Mediterranean coastal ecosystems. Ecological Indicators 11, 328-336.

Neher, D.A., Darby, B.J., 2006. Computation and application of nematode community indices: general guidelines. In: Abebe, E. (Ed.), Freshwater Nematodes: Ecology and Taxonomy. CABI, pp. 211-222.

Parker, J.G., 1983. A comparison of methods used for the measurement of organic matter in sediments. Chemistry and Ecology 1, 201-210.

Platt, H.M., Warwick, R.M., 1983. Free-living Marine Nematodes. Part. I. British Enoplids. In: Synopses of the British Fauna, vol. 28. Cambridge University Press, Cambridge.

Platt, H.M., Warwick, R.M., 1988. Free-living Marine Nematodes. Part II. British Chromadorids. In: Synopses of the British Fauna, vol. 38. E.J. Brill/Dr Backhuys, Leiden.

Platt, H.M., Shaw, K.M., Lambshead, P.J.D., 1984. Nematode species abundance patterns and their use in the detection of environmental perturbations. Hydrobiologia 118, 59-66.

R Development Core Team, 2011. R: A Language and Environment for Statistica Computing. R Foundation for Statistical Computing, Vienna, Austria. Available at: http://www.R-project.org.

Renaud-Mornant, J., Gourbault, N., de Panafiew, J.B., Heleouet, M.N., 1981. Effets de la pollution par hydrocarbures sur la meiofauna de la baie de Morlaix. In: Amoco Cadiz, Consequences d'une Pollution Accidentale par les Hydrocarbures. Actes coli. Intern. C.O.B., Brest (France), 19-22 November 1979, pp. 551-561.

Rudnick, D.T., Elmgren, R., Frithsen, J.B., 1985. Meiofaunal prominence and benthic seasonality in a coastal marine ecosystem. Oecologia 67, 157-168.

Schratzberger, M., Warr, K., Rogers, S.I., 2006. Patterns of nematode populations in the southwestern North Sea and their link to other components of the benthic fauna. Journal of Sea Research 55, 113-127.

Semprucci, F., Colantoni, P., Baldelli, G., Rocchi, M., Balsamo, M., 2010. The distribution of meiofauna on back-reef sandy platforms in the Maldives (Indian Ocean). Marine Ecology: An Evolutionary Perspective 31, 592-607.

Somerfield, P.J., Gee, J.M., Warwick, R.M., 1994. Soft sediment meiofaunal community structure in relation to a long-term heavy metal gradient in the Fal estuary system. Marine Ecology Progress Series 105, 79-88.
Somerfield, P.J., Fonseca-Genevois, V.G., Rodrigues, A.C.L., Castro, F.J.V., Santos, G.A.P., 2003. Factors affecting meiofaunal community structure in the Pina Basin, an urbanized embayment on the coast of Pernambuco, Brazil. Journal of the Marine Biological Association of the United Kingdom 83, 1209-1213.

Steyaert, M., Deprez, T., Raes, M., Bezerra, T., Demesel, I., Derycke, S., Desmet, G., Fonseca, G., Franco, M.A., Gheskiere, T., Hoste, E., Ingels, J., Moens, T., Vanaverbeke, J., Van Gaever, S., Vanhove, S., Vanreusel, A., Verschelde, D., Vincx, M., 2005. Electronic Key to the Free-living Marine Nematodes. Available at: http://nemys.ugent.be/.

Tietjen, J.H., 1980. Population structure and species distribution of the free living nematodes inhabiting sands of the New York Bight apex. Estuarine, Coastal and Shelf Science 10, 61-73.

Turner, R.K., 2000. Integrating natural and socio-economic science in coastal management. Journal of Marine Systems 25, 447-460.

Turner, S.J., Thrush, S.F., Pridmore, R.D., Hewitt, J.E., Cummings, V.J., Maskery, M., 1995. Are soft-sediment communities stable? An example from a windy harbour. Marine Ecology Progress Series 120, 219-230.

Van Gaever, S., Galéron, J., Sibuet, M., Vanreusel, A., 2009. Unravelling deep-sea habitat heterogeneity based on meiofauna communities in the Gulf of Guinea. Deep-Sea Research II 56, 2259-2269.

Van Gaever, S., Vanreusel, A., Hughes, J.A., Bett, B.J., Kiriakoulakis, K., 2004. The macro- and micro-scale patchiness of meiobenthos associated with the Darwin Mounds (north-east Atlantic). Journal of the Marine Biological Association of the United Kingdom 84, 547-556.

Vanaverbeke, J., Merckx, B., Degraer, S., Vincx, M., 2011. Sediment-related distribution patterns of nematodes and macrofauna: two sides of the benthic coin? Marine Environmental Research 71, 31-40.

Vanreusel, A., 1990. Ecology of the free-living marine nematodes from the Voordelta (Southern Bight of the North Sea). 1. Species composition and structure of the nematode communities. Cahiers de Biologie Marine 31 (4), 439-462.

Venturini, N., Muniz, P., Rodríguez, M., 2004. Macrobenthic subtidal communities in relation to sediment pollution: the phylum-level meta-analysis approach in a south-eastern coastal region of South America. Marine Biology $144,119-126$.

Verschelde, D., Nicholas, W., Vincx, M., 2006. A review of the genera Croconema Cobb, 1920 and Pseudochromadora Daday, 1899 (Nematoda, Desmodoroidea): new species from the Coasts of Kenya and Australia. Hydrobiologia $571,17-40$.

Warwick, R.M., 1988. The level of taxonomic discrimination required to detect pollution effects on marine benthic communities. Marine Pollution Bulletin 19, 259-268.

Warwick, R.M., Platt, H.M., Somerfield, P.J., 1998. Free-living Marine Nematodes. Part III. Monhysterids. In: Synopses of the British Fauna, vol. 53. Field Studies Council, Shrewsbury.

Wentworth, C.K., 1922. A scale of grade and class terms for clastic sediments. Journal of Geology 30, 377-392.

Wieser, W., 1953. Die Beziehung zwischen Mundhöhlengestalt, Ernährungsweise und Vorkommen bei freilebenden marinen nematoden. Arkiv for Zoology 4, 439-484. 